\title{
Determinants of Stock Price in Nepalese Market
}

\author{
Ramesh Raj Ghimire* and Deepashree Mishra**
}

\begin{abstract}
The aim of this study is to determine the relationship between stock price and explanatory variables like: DPS, EPS, P-E ratio, BV, Market to BV for the period 2012 to 2017. Using simple and multiple regression analysis and descriptive statistics this study investigates the factor affecting the stock price. With the sample size of 11 financial and nonfinancial firms of Nepal, the result indicates that the variables Market to $B V, P$-E ratio are the significant determinants of stock price which directlyaffect the stock price. Likewise, DPS, BV also have significance positive influence on stock price whereas EPS has minimum influence on the stock price.
\end{abstract}

Key Words: Dividend per share, Earning per share, Price-earning ratio, Book Value, Market to Book value

*Faculty at Nepal College of Management, Kathmandu University, Email: rameshrghimire@ gmail.com **Freelance researcher, Email: deepashree643@ gmail.com 


\section{Introduction}

The history of Capital market is not too long in Nepal. Capital market begun in Nepal with the IPO of Nepal Bank Limited and Biratnagar jute mills in 1937 AD. Securities Exchange center was established in 1976 AD with an objective of facilitating and promoting the growth of capital; later converted into Nepal stock Exchange whereas, NEPSE trading floor began on $1994 \mathrm{AD}$.

Stock market is the mirror of economy. It has become an essential market playing a vital role in economic prosperity that fostering capital formation and sustainable economic growth. Stock markets are more than a place to trade securities; they operate as a facilitator between savers and users of capital by means of pooling of funds, sharing risk, and transferring wealth. Stock markets are essential for economic growth as they insure the flow of resources to the most productive investment opportunities (Kurihara, 2006). It helps in growth of industry and commerce of the country that eventually affects the economy of the country to a great extent. This is the reason that all sectors like government, industry, corporation and even the central banks of the country keep a close watch on the happening of the stock market. Stock market is a medium through which small and scattered saving of investors are directed in productive activities of corporate entities. It also provides the essential attributes of liquidity, marketability and safety of investments to the investors. A well-organized and well-regulated capital market facilitates sustainable development of economy by providing long term fund in exchange for financial assets to investors. Hence, every government strives to develop and grow their capital market through various legislative and regulatory measures.

Since stock market is the place where people get rich quickly, it has been receiving the most attention from the media and also public interest has been increasing towards stock market. But we cannot deny the fact that it depends on various factors and time, otherwise it won't take a time to make people rich to poor. Therefore, this study aims to direct the investors to consider various determinants presented in this study before investment decision rather than on rumors and intuition. Here, the researcher will focus on the fundamental factors which directly influence the share price movement and on the basis of this report the investor could make their investment portfolio

Since large numbers of people are directed toward stock market and we are also aware about the volatility in stock market, so to safeguard the investors' investment on stocks this research will be directed toward identifying the factors affecting the stock price.

Several researchers have conducted research in this particular topic but only focusing on single or few sectors. So, the present study also aims to investigate the factors affecting the stock price by focusing on several sectors like commercial banks, Development banks, Micro finance, Hydropower and Hotels of Nepal. For this, the present researcher 
considered single statement of the problem that reads as- if there is any relationship between DPS, EPS, P-E ratio, BV, Market to book value and Price of stock? The purpose of this study is to analyze the influence of earning, P/E, dividend rate, Book Value, Market to book value on stock price.

The rest of this paper is presented as working hypothesis in section II, review of literature in section III followed by research methodology in section IV, presentation and analysis in section $\mathrm{V}$ and concluding remarks and managerial implications are presented in section VI.

\section{Hypothesis formulation}

Based on the objectives mentioned above, the following hypotheses have been developed. H01: There is no statistically significant relationship between EPS and stock price H02: There is no statistically significant relationship between DPS and stock price H03: There is no statistically significant relationship between $\mathrm{P} / \mathrm{E}$ ratio and stock price H04: There is no statistically significant relationship between Book Value and stock price H05: There is no statistically significant relationship between Market to Book value and stock price

\section{Review of Literature}

3.1 Conceptual Understanding on Factor Causing Volatility in Stock Price

Geetha and Swaaminathan (2015) have shown their view on market price as the average price of share derived from the financial year high and low. It is the current price at which an asset or service can be bought or sold. Where, High price equals to highest market price during the financial year and Low price equals to the lowest market price during the financial year and calculated as:

Market price $=($ high price + Low price $) / 2$

Different scholars have provided their different view regarding the determinants of stock price which can be presented as:

\section{1) Earning Per Share (EPS)}

Geetha and Swaaminathan (2015) have referred it as the ratio of the profit after tax of the company for any financial year after the payment of preference dividend. The equity share holders are the sole claimer of the net earnings of the corporation after making payment of dividend to the preference shareholders. They also stated that the significance of this ratio flows from the fact that higher the earnings per share the more is the scope for a higher rate of dividend and also of retained earning, to build up the inner strength of the company. It is calculated as:

EPS = Net profit after tax - Preferred dividend/Number of outstanding shares 


\section{2) Dividend Per share (DPS)}

Geetha and Swaaminathan (2015) have stated it as the portion of the profit after tax, which is distributed to the shareholders for their investment bearing risk in the company. They also added that it has a significant influence on the market price of the share. It has a significant influence on the market price of the share. DPS shows how much the company has paid out as a dividend. It refers to the actual amount of dividend i.e. gross dividend declared per share. The net profit after taxes belongs to shareholders but the income that they really receive is the amount of earnings distributed and paid as cash dividend. It is calculated as:

\section{DPS= Dividend/Number of outstanding shares}

\section{3) Price Earning Ratio (P-Eratio)}

Geetha and Swaaminathan (2015) pointed that this ratio enables an investor to make appropriate calculation of the time required to cover the investment in a company's stock. $\mathrm{P}$-E ratio expresses the relationship between the market price of a company's share and its earning per share. It indicates the extent to which the earning of each share is covered by its price. It is calculated as:

\section{$P-E$ Ratio= MP/EPS}

\section{4) Book Value (BV)}

Book value is also known as net asset value per share because it measures the amount of assets, which the corporation has on behalf of each equity share. BV shows the net investment per share made in business by the shareholder. It is the value at which an asset is carried on a balance sheet (Bondt, 2008). It is calculated as:

\section{$B V=($ Reserve + EquityCapital- Revaluation Reserve $)$ Wumber of outstanding shares}

\subsection{Review of Related Studies}

Almumani (2014) has conducted the research to examine the empirical relationship between stock price and selected variables: book value per share, dividend per share, earning ratio, dividend payout, and size in terms of total assets. Researcher has taken a sample of 7 Jordanian banks and 49 observations (including branches of 7 banks) over the 2005-2011 interval period listed on Amman Stock Exchange (ASE). This study dealt with fundamental analysis of share valuation by using correlation, Regression, Ratio which revealed that variables earning per share, book value per share, price earning ratio, and size are significant determinants of stock price.

Here, Researcher suggested investor to take care of these variables before making any investment.

Bhattarai (2014) researched on determinants of share price of commercial banks listed on the Nepal Stock Exchange over the period of 2006 to 2014. This study has adopted 
descriptive as well as causal comparative research design i.e. correlation and regression analysis by taking sample size of 9 commercial bank from population of all bank listed on NEPSE using convenient sampling method for the study. To conduct this study, researcher has taken dividend payout ratio, dividend yield, earning per share, P-E ratio, size as variable. The finding of this study revealed that earning per share and price-earnings ratio have the significant positive association with share price while dividend yield showed the significant inverse association with share price of the bank. The study concluded that dividend yield, earning per share and price-earnings ratio are the major determinants share price of Nepalese commercial banks.

Pradhan and Dahal (2016) have examined the factors affecting the share price of Nepalese commercial banks listed on NEPSE. A sample size of 14 banks listed in NEPSE was selected for the period 2002/03 to 2013/14. The multiple regression model were estimated to test the impact of selected variables on stock price which revealed earning price per share, dividend per share, price earning ratio, book value per share, return on assets and size as major determinants of stock price in context of commercial banks in Nepal.

Balkrishna (1984) has analyzed the relationship between explanatory variables namely dividend per share, Earning per share, book value of share, yield, cover and market price of share. Researcher has used linear regression model to study the relation of those variables in general engineering and cotton textile industries which revealed that Book value per share and dividend per share as most significant determinants of market price in both the industries. Yield also emerged as a significant determinant of stock price associated negatively in cotton textile industry.

\section{Research Methodology}

This research has used descriptive and pooled cross- sectional research design and has used crossed sectional data from secondary sources such as official website of Nepal Stock Exchange and annual reports of sample firm to conduct this study.Data is collected for the period of 2012 to 2017. The annual data published on their websites are audited by the auditors and also approved by government for taxation purposes so the data used in present study were assumed to be valid. Since this study is conducted to analyze the factor affecting the stock price by using the secondary data so this study has only considered those firms which are listed in NEPSE. Moreover, every firm cannot be studied in short period of time so researcher has focused on those firms operating in Kathmandu, Lalitpur and Bhaktapur.Commercial banks, Development banks, Hydropower, Micro finance, Hotels and Life and non-life insurance are the unit analyzed in this study. The sample firms are:

\section{Commercial Bank}

i. Standard Chartered Bank (SCB) 
ii. Everest Bank Ltd. (EBL)

\section{Development Bank}

i. MuktinathBikash Bank Ltd. (MNBBL)

ii. JyotiBikash Bank Ltd (JBBL)

\section{Hydropower}

i. Chilime Hydropower Company Limited (CHCL)

ii. Butwal Power Company Limited (BPCL)

\section{Micro Finance}

i. NirdhanUtthanLaghubittaBittiyaSanstha Ltd (NUBL)

\section{Insurance Comapny}

i. Sikhar Insurance Co. Ltd. (SICL)

ii. Nepal Life insurance Co. Ltd. (NLIC)

\section{Hotel}

i. Oriental Hotels ltd. (OHL)

ii. Taragaon Regency Hotel Ltd. (TRH)

In this way total sample size of this study are 11, which has guided the entire study.

\section{Presentation and analysis}

\subsection{Component wise analysis of Stock Price}

This section presents the factors that influence the stock price fluctuation in Nepalese Share market

\section{Table 1}

\section{Descriptive Statistics Table}

This table shows the Descriptive Statistics of factors influencing stock price. DPS is defined as the sum of declared dividends issued by a company for every ordinary share outstanding. EPS means a portion of a company's profit allocated to each outstanding share of common stock. P-E ratio is the measure of the share price relative to the annual net income earned by the firm per share. Similarly, Book value is defined as the value of the company according to its "books" or financial statements where as the Market to Book value ratio is used to find the value of a company by comparing the book value of a firm to its market value 


\begin{tabular}{lrrrccr}
\hline & & & & & Std. De- & \\
& N & Minimum & Maximum & Mean & viation & Variance \\
\hline DPS & 66 & 0 & 126.31 & 33.6862 & 25.5956 & 655.134 \\
EPS & 66 & 7.47 & 309 & 58.6474 & 59.3281 & 3519.83 \\
P-E & 66 & 3.57 & 361.1 & 37.7014 & 57.2935 & 3282.54 \\
BV & 66 & 59.4 & 393.59 & 207.427 & 88.8327 & 7891.25 \\
MKt- & 66 & 0.0179 & 12.6466 & 2.1141 & 3.28563 & 10.795 \\
BV & & & & & & \\
Price & 66 & 30.2 & 4380 & 1117.85 & 1127.75 & 1271831 \\
\hline
\end{tabular}

Table 1 shows the descriptive statistics of 11 companies listed on NEPSE from 2012 to 2017. Descriptive statistics shows that, the mean of the DPS is 33.686 with standard deviation of 25.596 and ranges from 0 to 126.31. This implies that, value of DPS can deviate on both sides by 25.596 and the mean of the EPS is 58.647 with standard deviation of 59.328 and ranges from 7.47 to 309 which means the value of EPS can deviate on both sides by 59.328 . Similarly, P-E ratio has mean value of 37.701 and standard deviation of 57.2934 ranging from 3.57 to 361 which means the value can be deviated by 57.2234. Moreover, Book value whose mean and standard deviation is 207.427 and 88.8832 respectively. It has minimum value of 59.4 and maximum value of 393.59 which can be deviated by 88.8832 . Likewise, Market to BV has mean value of 2.114 and standard deviation of 3.2856, ranging from 0.179 to 12.647 implies that value can be deviate by 3.2856 on both sides. Finally, stock price has mean value, standard deviation and minimum and maximum range of 1117.847 , 1127.755 , and 30.2 to 4380 respectively shows that minimum and maximum value can be deviated by 1127.755 .

\section{Table 2 \\ Correlation Coefficient}

This table shows the Correlation of stock price and factors affecting stock price. DPS is defined as the sum of declared dividends issued by a company for every ordinary share outstanding. EPS means a portion of a company's profit allocated to each outstanding share of common stock. P-E ratio is the measure of the share price relative to the annual net income earned by the firm per share. Similarly, Book value is defined as the value of the company according to its "books" or financial statements where as the Market to Book value ratio is used to find the value of a company by comparing the book value of a firm to its market value 


\begin{tabular}{lllllll}
\hline FACTORS & DPS & EPS & P-E & BV & $\begin{array}{l}\text { MKt- } \\
\text { BV }\end{array}$ & Price \\
\hline DPS & 1 & & & & & \\
EPS & -0.097 & 1 & & & & \\
P-E & 0.131 & -0.161 & 1 & & & \\
BV & 0.45 & -0.119 & -0.088 & 1 & & \\
MKt-BV & 0.393 & 0.036 & 0.122 & 0.394 & 1 & \\
Price & 0.498 & -0.098 & 0.592 & 0.456 & 0.616 & 1 \\
\hline
\end{tabular}

The given Table 2 shows correlation between various factors of stock price. The major focus in this table is to show the relationship between various factors such as Dividend per share (DPS), Earning Per Share (EPS), Price-Earnings Ratio (P-E), Book value (BV), Market to book (Market to BV) and Price of stock. From the table, it can be implied that among Five factors, Market to BV is found to be strongly correlated with stock price i.e. 0.616. Likewise, P-E ratio and stock price have moderate correlation with each other with 5.92 and Book value and Price of stock have 0.456 correlation score resulting a moderate influence over each other and same moderate correlation can be traced between DPS and Price of stock whereas EPS and Price have week positive correlation. As with the price, EPS have weak negative correlation with other factors like P-E ratio, BV but have weak positive correlation with market to BV with 0.036 .Similarly, P-E ratio have weak negative correlation with market to BV with 1.22.

The regression result of DPS, EPS, P-E ratio, BV and market to book value is presented in the given Table 3 . The first five models include one of five independent variable or explanatory variable at a time and model 6 include two independent variable i.e. DPS and EPS. Model 7 include two variables i.e. EPS and P-E ratio whereas model 8 and 9 each includes two independent variable i.e. P-E ratio and Book value and Book value and market to Book value respectively. Likewise model 10 includes 3 independent variable i.e. DPS, EPS and P-E ratio and model 11, 12 also includes 3 independent variables. Model 11 includes EPS, P-E ratio, Book value whereas model 11 includes P-E ratio, Book value and market to Book value.

Moreover, model 13, 14, each includes 4 variables. Model 13 includes DPS, EPS, P-E ratio, Book value and Model 14 includes EPS, P-E ratio, Book value and market to Book value whereas model 15 include all variable simultaneously. 
Model 1,3,4,5 have beta coefficient positive for DPS, P-E, Book value and market to Book value. The result shows that higher the DPS, P-E ratio, Book value and market to Book value higher would be the market price per share. However on model 2 Beta coefficients for EPS is negative implies that higher the EPS lower will be the stock price per share.

\section{Table 3: Estimated relationship between stock price and firm specific variables}

This table shows the relationship between share price and various fundamental factors affecting share price in Nepal (Regression Analysis table).DPS is defined as the sum of declared dividends issued by a company for every ordinary share outstanding. EPS means a portion of a company's profit allocated to each outstanding share of common stock. P-E ratio is the measure of the share price relative to the annual net income earned by the firm per share. Similarly, Book value is defined as the value of the company according to its "books" or financial statements where as the Market to Book value ratio is used to find the value of a company by comparing the book value of a firm to its market value.

\begin{tabular}{|c|c|c|c|c|c|c|c|c|}
\hline Model & Intercept & DPS & EPS & PE & BV & $\begin{array}{c}\text { Mrkt to } \\
\text { BV }\end{array}$ & $\mathbf{R 2}$ & F-Value \\
\hline & 378.503 & 21.948 & & & & & & \\
\hline \multirow[t]{2}{*}{1} & 1.879 & 4.596 & & & & & 0.248 & 21.122 \\
\hline & 1227.401 & & -1.868 & & & & & \\
\hline \multirow[t]{2}{*}{2} & 6.246 & & -0.79 & & & & 0.432 & 0.624 \\
\hline & 678.747 & & & 11.647 & & & & \\
\hline \multirow[t]{2}{*}{3} & 5.016 & & & 5.872 & & & 0.35 & 34.377 \\
\hline & -82.416 & & & & 5.786 & & & \\
\hline \multirow[t]{2}{*}{4} & -0.259 & & & & 4.097 & & 0.208 & 16.782 \\
\hline & 670.645 & & & & & 211.533 & & \\
\hline \multirow[t]{2}{*}{5} & 5.108 & & & & & 6.261 & 0.38 & 39.194 \\
\hline & 442.225 & 21.733 & -0.963 & & & & & \\
\hline \multirow[t]{2}{*}{6} & 1.804 & 4.502 & -0.462 & & & & 0.251 & 10.538 \\
\hline & 682.877 & & -0.064 & 11.636 & & & & \\
\hline \multirow[t]{2}{*}{7} & 3.665 & & -0.033 & 5.745 & & & 0.35 & 16.97 \\
\hline & -702.934 & & & 12.536 & 6.499 & & & \\
\hline \multirow[t]{2}{*}{8} & -2.955 & & & 8.064 & 6.483 & & 0.61 & 49.304 \\
\hline & 78.726 & & & & 3.201 & 177.439 & & \\
\hline \multirow[t]{2}{*}{9} & 0.288 & & & & 2.444 & 5.011 & 0.434 & 24.107 \\
\hline & 45.354 & 18.95 & 0.57 & 10.629 & & & & \\
\hline 10 & 0.22 & 4.887 & 0.339 & 6.084 & & & 0.729 & 23.381 \\
\hline
\end{tabular}




\begin{tabular}{ccccccccc} 
& -811.327 & & 1.291 & 12.766 & 6.615 & & & \\
11 & -2.995 & & 0.842 & 8.07 & 6.522 & & 0.615 & 32.954 \\
& $-511 . .625$ & & & 11.258 & 4.372 & 141.002 & & \\
12 & -2.619 & & & 8.814 & 4.915 & 5.841 & 0.749 & 61.525 \\
& -848.27 & 10.614 & 1.355 & 11.96 & 5.198 & & & \\
\multirow{2}{*}{13} & -3.298 & 2.823 & 0.933 & 7.834 & 4.792 & & 0.659 & 29.488 \\
& -546.532 & & 0.4 & 11.338 & 4.423 & 140.035 & & \\
\multirow{2}{*}{14} & -2.426 & & 0.318 & 8.648 & 4.86 & 5.715 & 0.749 & 45.5 \\
& -592.001 & 6.539 & 0.514 & 10.964 & 3.738 & 128.026 & & \\
15 & -2.679 & 2.016 & 0.42 & 8.481 & 3.931 & 5.195 & 0.765 & 39.041 \\
\hline
\end{tabular}

\section{Dependent variable: Price}

Similarly, the result of model 15 suggests that independent variable i.e. DPS, EPS, P-E ratio.Book value and market to Book value significantly explains dependent variable i.e. Stock price with regression line/model given by following:

\section{Price $=-592.001+6.539 D P S+0.514 E P S+10.964 P-E+3.738 B V+128.026 M K t$ to $B V$}

Regression model shows the dependency of the factors. The positive beta coefficient of factors represent higher those factors higher will be the price of stock.

Lastly, model 6 indicates that Market to Book value is more important in predicting Price of stock than other variable whereas EPS is least important in predicting the stock price.

\section{Concluding Remarks}

The stock market is all about dynamics and that is why investors and fund managers have been time and again confronted with the problem of accurately predicting the stock prices so as to earn decent returns. Investment in shares offers the benefit of liquidity as well as the opportunity to beat the market and earn high returns. But the task of predicting share prices is far from simple. Share price movement is not dependent in nature and both intrinsic as well as extrinsic factors have been established to exerciser influence over stock price movement. Using multiple regression analysis and descriptive statistics this study investigates the factor affecting the stock price. The study has chosen DPS, EPS,P-E ratio, $\mathrm{BV}$, market to $\mathrm{BV}$ as the major variable of stock price with the sample size of 11 financial and nonfinancial firms.

The result indicates that the variables Market to BV, P-E ratio are the significance determinants of stock price which affects the stock price in direct manner. Likewise, DPS, $\mathrm{BV}$ also have significance positive influence on stock price but EPS has minimum influence 
on the stock price. Many researchers have conducted research in this particular topic and most of them have found positive relationship between EPS and Market price whereas present researcher has shown minimum influence of EPS in stock price. EPS can be never studied in isolated form. For instance, Increase in EPS means firms are most likely to give dividend in near future but in current scenario, NRB the regulator of banking institutions has imposed regulation to raise the capital of banking institution. In such situation, banks are most likely to retain their profit with themselves rather than distributing it as dividend to stockholders as a result fund manager and other investors are not taking EPS as factors to be considered while making investment decision. So here, despite of increase in EPS it is not contributing to market price. Therefore, minimum influence is traced between these factors in this recent study and probably such findings can be traced in future research as well until the capital problem of bank is solved. Finally, the results of this study uncovered new evidence in Nepalese perspective, which are considered to be valuable to market participants. Thus, findings of this study seems to be particularly useful for the share investors, fund manager and economy as well, as they can watch out for these significant factors while estimating stock returns and predicting share prices.

\subsection{Recommendations for Managerial Implications}

Good quality institutions are important for development of stock market. Well established institution reduces political risk which is major issue in Nepalese context and, an important factor in investment decisions. The development of good quality institutions such as law and order, efficient bureaucracy, and democratic accountability is therefore crucial for stock market development in emerging economies like Nepal. Further, research can be conducted considering macroeconomic variables like money supply, exchange rate etc.

Various measurement tool and technique should be developed in order to derive maximum benefit from stock markets. In order to enable the capital market in general and stock market in particular to take full advantage of various opportunities and cope up with challenges, macroeconomic variables like inflation, interest rates, inflation, should also be reduced. This must be done in relation to appropriate monetary policies to ensure macroeconomic stability.

\section{References}

Almumani, M. A. (2014). "Determinants of equity share prices of the listed banks in Amman stock exchange: Quantitative approach". International Journal of Business and Social Science, 5(1), 91-104.

Almumani, M.A. (2014). "Determinants of equity share prices of the listed banks in Amman stock exchange: Quantitative approach". International Journal of Business and social Science, 5(1): 91-104 
Aurangzeb. (2012). "Factors affecting performance of stock market: Evidence from South Asian countries". International Journal of Academic Research in Business and social sciences, 2(9): 1-12

Balkrishan,(1984). “Determinants of Equity Prices in India”. Management Accountant, 19(12), 728-730.

Bhatta, G.P(2010). "Does Nepalese Stock Market Follow Random Walk?" SEBON Journal, $4: 18-58$.

Bhattarai, Y.R.(2014) "Determinants of Share Price of Nepalese Commercial Banks". Economic Journal of Development Issues Vol, 17 \& 18 No. 1-2

Cooper, D. R., et al. (2006). Business research methods, Mcgraw-Hill Irwin New York.

Dangol, J. (2010). "Testing Random-Walk Behavior in Nepalese Stock Market." PYC Nepal Journal of Management, 3(1) : 28-36.

Dangol, J. 2008. "Unanticipated Political Events and Stock Returns: An Event Study."Economic Review, 20 : 86-110.

Enow, S.T \&Brijlal, P. (2016). "Determinants of Share Prices: the Case of Listed Firms on Johannesburg Stock Exchange”. Journal of Accounting and Management, 6(1): 85 92

Enow, S.T., \& Brijlal, P. (2016). "Determinants of Share Prices: the case of Listed Firms on Johannesburg Stock Exchange". The Journal of Accounting and Management, Vol 6

Furgang, K. (2010). How the stock market works (1sted.). New York: Rosen Publishing

Joshi. R. 2012. "Effects of Dividends on Stock Prices in Nepal."NRB Economic Review, $24(2), 61-75$

Kurihara, Utaka,2006, “The Relationship between Exchange Rate and Stock Prices during the Quantitative Easing Policy in Japan”, International Journal of Business, Vol. 11, No.4: 375-386

Malhotra, N. and Tandon, K. (2013). "Determinants of stock prices: Empirical evidence from NSE 100 Companies". International Journal of Research in Management \& Technology, 3(3):89-95

Malhotra, N.k. (2007). Marketing Research: An Applied Approach. India: Prentice Hall/ Finance Times 
Nirmala, P.S. Sanju, P.S Ramachandran, M. (2011). "Determinants of share prices in India". Journal of Emerging Trends in Economic and Management science, 2 (2):124-130

North,C., \& Cases, C.J.(2012). The Stock Market(1sted.). New York:The Rosen Publishing Group, Inc

Saunder, A., Cornett, M.C. Financial Markets and Institution (3rd ed.). US.A: McGraw Hill India

Saunders, M., Lewis, P., \&Thornhill, A. (2004). Research Methods for Business Students. (3rd ed.) Pearson Education

Sekaran, U., Bougie, R., (2016). Research Methods for Business: A skill Building Approach (7thed.). UK: John Wiley \& sons, Inc

Sharif, T., Purohit, H., \& Pillai, R. (2015). "Analysis of Factors Affecting Share Prices: The Case of Bahrain Stock Exchange". International Journal of Economics and Finance, 7, 207-216.

Sharma, S. (2011). "Determinants of equity share prices in India". Journal of Arts, Science \& commerce, 2(4):51-60

Sharma, S. (2011). "Determinants of equity share prices in India". Journal of Arts, Science \& Commerce, 2(4), 51-60.

Shiller, R.J. (1992). Market Volatility (1st ed.). London: The MIT press

Sukhija, S. (2104). "Fundamental Determinants affecting Equity Share Price of BSE- 200 Companies in India". European Journal of Business and Management, vol6

Teweles, R.J., \& Bradley E.S. (1998). The Stock Market (7thed.). New York: John Wiley \& sons, Inc

Uddin, M. B. 2009. "Determinants of market price of stock: A study on bank leasing and insurance" Journal of Emerging Trends in Economics and Management Sciences, 2(2):124-130 ISSN: 2141-7024

Zahir, M. A. and Khanna, Y. 1982."Determinants of Stock Prices in India”. The Chartered Accountant, 30(8): 521-523. 